\title{
MEMANFAATKAN BARANG BEKAS UNTUK MENUMBUHKAN EKONOMI KREATIF DI KALANGAN MASYARAKAT (Pada Majelis Ta'lim Al Hidayah Benda Baru Pamulang)
}

\author{
${ }^{1}$ Gunartin, ${ }^{2}$ Badrus Sholeh, ${ }^{3}$ Metha Lubis \\ Dosen Fakultas Keguruan dan Ilmu Pendidikan \\ Email : 1ㅇosen01339@unpam.ac.id
}

\begin{abstract}
ABSTRAK
Ekonomi kreatif merupakan konsep yang menitikberatkan pengembangan nilai tambah suatu barang melalui kreativitas dan inovasi untuk menggerakkan ekonomi. Sampah merupakan barang yang secara ekonomis sudah tidak bernilai yang dihasilkan oleh kegiatan manusia ataupun dari alam sehingga tidak mempunyai nilai manfaat. Namun sampah ini akan mempunyai manfaat kembali jika didaur ulang dengan sentuhan kreatif dan mengubahnya menjadi barang yang bernilai guna serta bernilai ekonomi.

Majelis Ta'lim Al Hidayah diprakakasai dengan tujuan di komplek perumahan Pamulang Regency ada ajang silaturrohim dan wadah kajian ke Islam an untuk sharing ilmu dan pengalaman. Secara bertahap selama hampir 2 (dua) tahun ini jumlah anggota berkembang seiring berkembangnya jumlah penghuni perumahan Pamulang Regency. Sekarang jumlah jamaah Majelis Ta'lim Al Hidayah 40 orang karena tidak semua warga Pamulang Regency ikut dan beragama lain.

Tujuan yang ingin dicapai dalam kegiatan ini adalah untuk membangun ekonomi masyarakt melalui kegiatan menumbuhkan ekonomi kreatif di kalangan masyarakat dengan memanfaatkan barang bekas / daur ulang sampah, dengan harapan masyarakat mampu secara mandiri untuk memenuhi kebutuhan hidupnya serta menumbuhkan kreatifitas di kalangan masyarakat.
\end{abstract}

\section{Kata Kunci: ekonomi krearif, Barang bekas (sampah)}

\section{PENDAHULUAN}

Ilmu ekonomi dapat didefinisikan sebagai ilmu yang mempelajari penggunaan sumber daya yang terbatas oleh individu dan masyarakat untuk memenuhi kebutuhan konsumsinya dengan berbagai upaya memproduksi barang dan jasa (Sukirno, 2016). Sementara menurut Manurung dan Raharja (2008) ilmu ekonomi belajar tentang perilaku individu dan masyarakat dalam menentukan pilihan untuk memanfaatkan sumber daya sebagai upaya meningkatkan kualitas hidup. Dari kedua pendapat tersebut dapat disimpulkan bahwa ilmu ekonomi mempelajari bagaimana individu dan masyarakat menggunakan sumber daya yang terbatas untuk memenuhi kebutuhannya. 
Ekonomi kreatif merupakan konsep yang menitikberatkan pengembangan nilai tambah suatu barang melalui kreativitas dan inovasi untuk menggerakkan ekonomi. Juga merupakan pengembangan bakat individu yang berdaya kreasi dan daya cipta berdasarkan keterampilan dan kreativitas yang dimiliki (Darwanto, 2015). Definisi ekonomi kreatif menurut Departemen Perdagangan RI yaitu industry kecil dari pengembangan bakat melalui kreativitas dan keterampilan untuk menciptakan lapangan pekerjaan guna kesejahteraan.

Sampah merupakan barang yang secara ekonomis sudah tidak bernilai yang dihasilkan oleh kegiatan manusia ataupun dari alam sehingga tidak mempunyai nilai manfaat (Sejati, 2009). Berdasarkan sumbernya, sampah digolongkan bersumber dari pemukiman, tempat dagang, industri dan tempat umum ( Sumantri (2010). Sampat juga dapat digolongkan berdasarkan jenis yaitu berdasarkan zat kimia yang terkandung, berdasarkan dapat tidaknya dibakar dan berdasarkan karakteristik sampah (Notoadmodjo, 2007)

Salah satu strategi pemanfaatan sampah yaitu melalui daur ulang sampah (recycle) untuk memberi nilai ekonomis dan nilai guna sekaligus untuk mengurangi volume sampah. Recycle merupakan proses daur ualng yang tidak digunakan lagi hingga menjadi barang yang bermanfaat dan bernilai tambah (Zulkifli, 2014). Sampah yang secara umum digolongkan menjadi sampah orgamik dan sampah non organic melalui sentuhan keterampilan dan kreativitas dapat di daur ulang menjadi barang bernilai ekonomis. Contoh, sampah organic dapat didaur ulang untuk dijadikan kompos, sementara sampah non organic seperti kertas dapat dibubur atau dihancurkan dan diciptakan menjadi jenis barang.

Dalam kaitannya dengan menumbuhkan ekonomi kreatif di kalangan masyarakat merupakan sikap toleransi yang harus dikembangkan dan diberdayakan. Selain menumbuhkan jiwa entrepreneur di kalangan masyarakat juga membantu mengatasi permasalahan sampah yang menjadi masalah nasional. Sudah menjadi tanggung jawab masyarakat untuk memikirkan solusi pengelolaan sampah yang efektif. Maka dari itu melalaui program bank sampah yang telah melakukan pemilahan terhadap sampah dan sebagai tindak lanjut perlu penanganan yang lebih serius bagaimana memanfaatkan barang bekas yang notabene sudah tidak mempunyai nilai secara ekonomis diprosses/diolah untuk dijadikan barang yang bernilai ekonomis dan bernilai guna.

Sebagai akademisi dan bagian dari masyarakat yang mempunyai kewajiban untuk melakukan tridharma Perguruan Tinggi, maka pendidik juga harus ikut memikirkan dan membantu masyarakat yang membutuhkan perhatian dari pemerntah atau pihak lain sebagai mediator membangun ekonomi masyarakat terutama untuk ibu-ibu rumah tangga agar dapat membantu ekonomi keluarga. Penyuluhan yang akan dilaksanakan di kalangan ibu-ibu Majelis Ta'lim Al Hidayah ini dimaksudkan untuk berbagi pengetahuan dan keilmuan memanfaatkan barang yang sudah tidak difungsikan untuk diolah menjadi barang bernilai ekonomis dan bernilai guna. Juga untuk menumbuhkan kreatifitas masyarakat agar mampu berdaya cipta sehingga mampu menciptakan barang yang bernilai ekonomis dari barang bekas. 


\section{METODE PELAKSANAAN}

Metode pelaksanaan dalam kegiatan pengabdian kepada masyarakat ini diawali dengan melakukan wawancara dengan ketua Majelis Ta'lim Al Hidayah, sebagai langkah penjajakan bahwasanya diperkenankan melakukan kegiatan pengabdian kepada masyarakat. Adapun tahapan pelaksanaan program pengabdian kepada masyarakat sebagai berikut:

\section{Tahap Persiapan Pelaksanaan}

Tahap persiapan ini, dengan melakukan koordinasi secara intensif dengan anggota (tim) sebelum pelaksanaan kegiatan, dengan tujuan agar pelaksanaan kegiatan pengabdian kepada masyarakat dapat berjalan lancar. Persiapan pelaksanaan meliputi: menyiapkan materi penyuluhan, menyiapkan pemateri/narasumber, persiapan konsumsi, daftar hadir, spanduk, dokumentasi dan perlengkapan lain yang dibutuhkan terkait pelaksanaan kegiatan. Langkah ini dilakukan tim pengusul agar program pengabdian kepada masyarakat ini berjalan lancar dan tepat sasaran sesuai dengan tujuan dilakukannya pengabdian kepada masyarakat.

\section{Tahap Pelaksanaan Pengabdian Kepada Masyarakat}

Pengabdian kepada masyarakat dilaksanakan pada sore hari, hal ini mempertimbangkan bagi ibu-ibu anggota majelis ta'lim yang bekerja masih bisa mengikuti kegiatan PKM sepulang kerja. Susunan acara yang dibacakan oleh pembawa acara merupakan dimulainya kegiatan. Setelah sambutan dari perwakilan tin PKM, dilanjutkan oleh ketua Majeli Ta'lim Al Hidayah merupakan rangkaian awal sebelum masuk materi penyuluhan. Materi memanfaatkan daur ulang sampah untuk menumbuhkan ekonomi kreatif yang disajikan kurang lebih empat puluh lima menit tersebut dilaksanakan dengan seksama oleh peserta dan dilanjutkan diskusi dengan ibu-ibu jamaah majelis ta'lim. Pembacaan doa yang dilakukan oleh salah satu dosen sekaligus menutup rangkaian kegiatan PKM

\section{Tahap Pelaporan Hasil Pengabdian}

Pada tahan pelaporan hasil pengabdian kepada masyarakat ini merupakan laporan serangkaian kegiatan mulai dari surve pra pengabdian hingga pelaporan kegiatan. Adapun hasil dari kegiatan ini, selain warga Pamulang Regency jamaah Majelis Ta'lim Al Hidayah mendapatkan manfaat sharing ilmu selain ilmu agama, juga kegiatan PKM dapat dilakukan secara berkelanjutan di masa yang akan datang. pondasi yang kokoh untuk rencana taktis anda dan memungkinkan anda untuk mengembangkan tujuan serta harapan yang masuk akal.

Untuk menentukan peluang keberhasilan dan menetapkan strategi pemasaran (marketing plan) anda, anda harus memahami kompetisi. Melakukan riset terhadap kompetisi terlebih dahulu juga akan membantu anda dalam melalui langkah berikutnya dalam menciptakan analisis SWOT.

Dalam dunia pemasaran menyeluruh (inbound marketing), ada berbagai strategi yang bermanfaat yang bisa anda gunakan. Strategi-strategi ini juga bisa berguna ketika anda ingin melakukan riset terhadap kompetitor anda. 


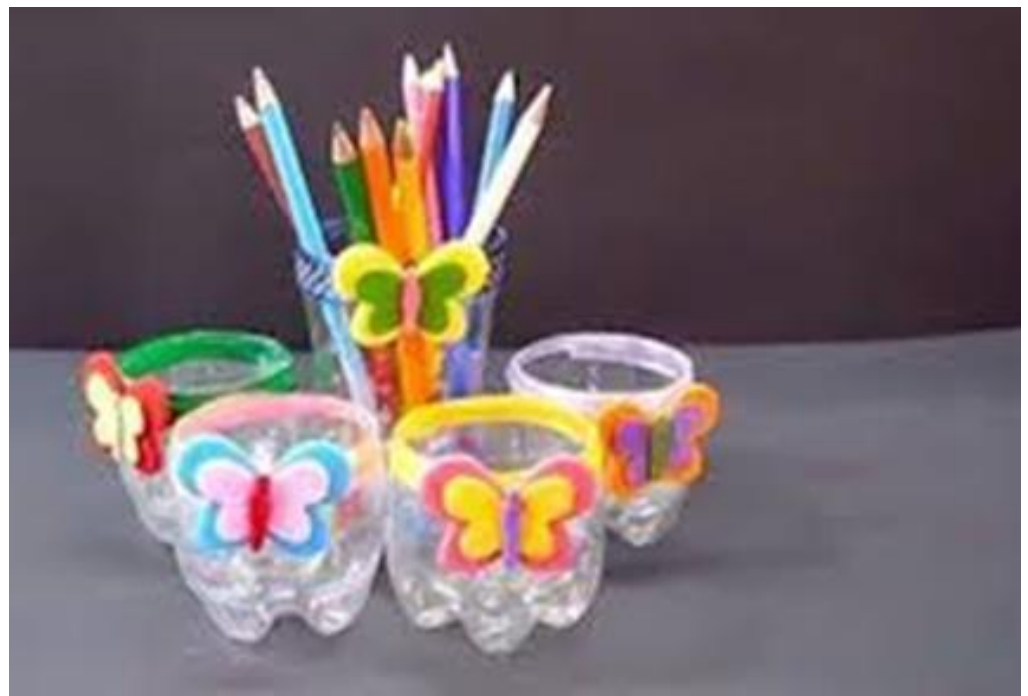

Gambar 1. Hasil Kreasi Pembuatan Bahan Bekas

\section{HASIL DAN PEMBAHASAN}

Majelis Ta'lim Al Hidayah yang berlokasi di RT. 008 RW 005 Kelurahan Benda Baru Kecamatan Pamulang Tangerang yang berdiri 10 Oktober 2017 dengan anggota ibu-ibu di komplek perumahan Pamulang Regency. Majelis Ta'lim Al Hidayah ini didirikan sebagai wadah kajian ke Islam an dan ajang silaturrohim bagi warga penghuni perumahan Pamulang Regency. Majelis Ta'lim Al Hidayah diprakakasai dengan tujuan di komplek perumahan Pamulang Regency ada ajang silaturrohim dan wadah kajian ke Islam an untuk sharing ilmu dan pengalaman. Secara bertahap selama hampir 2 (dua) tahun ini jumlah anggota berkembang seiring berkembangnya jumlah penghuni perumahan Pamulang Regency. Sekarang jumlah jamaah Majelis Ta'lim Al Hidayah 40 orang karena tidak semua warga Pamulang Regency ikut dan beragama lain.

Hasil dari pemberian penyuluhan manfaat daur ulang sampah, memberikan wawasan bagi ibu-ibu rumah tangga, bahwanya penyumbang sampah terbesar berasal dari rumah tangga. Untuk itu menjadi sangat penting kesadaran masyarakat untuk meminimalkan sampah, setelah sharing tentang bahayanya sampah jika dibiarkan. Sampah memang menjadi ancaman jika tidak dikelola dengan baik, tetapi sampah juga bisa mendatangkan manfaat jika dikelola dengan baik. 


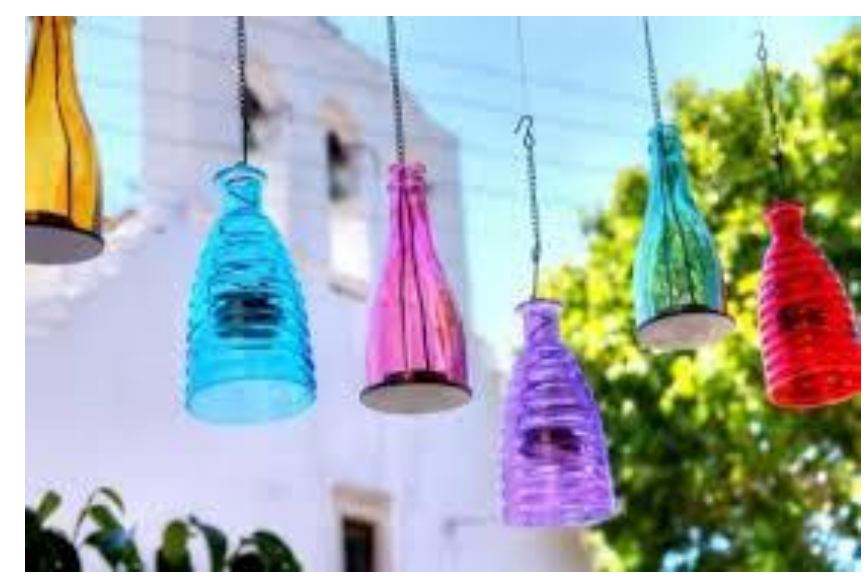

Gambar 2. Hiasan Gantungan Barang Bekas

Pengelolaan sampah secara efektif merupakan tugas dan tanggung jawab masyarakat, karena masyarakatlah yang menghasilkan sampah. Beberapa program telah diluncurkan oleh pemerintah dalam pengelolaan sampah, namun volume sampah tetap saja meningkat dari waktu ke waktu sehingga butuh perhatian khusus untuk mengelola sampah. Salah satu bentuk pengelolaan sampah adalah dengan memisahkan sampah mulai dari rumah tangga, dipilah berdasarkan jenis sampah yaitu sampah organic dan sampah non organik. Sampah non organic yang berbahan baku plastic khususnya dapat didaur ulang menjadi vas bunga, bunga plastic, tempat tanaman hidro ponik, dan sebagainya. Dengan sedikit sentuhan kreatifitas, barang bekas / sampah dirubah wujud dan bentuknya, tidak saja mendukung program minim sampah tetapi lebih pada menumbuhkan ekonomi kreatif masyarakat yang harapannya dapat dikembangkan menjadi ekonomi produktif sebagai tambahan penghasilan keluarga.

Gambar yang ditampilkan merupakan contoh pemanfaatan sampah plastic (botol aqua) yang dapat di daur ulang menjadi hiasan ataupun peralatan yang mempunyai nilai guna. Jika ini dikembangkan terus tidak saja menumbuhkan kreatifitas di kalangan masyarakat tetapi sampah plastic juga dapat diminimalkan. Pada kegiatan PKM kali ini baru sebatas memberikan penyuluhan pemanfaat barang bekas (sampah) untuk menumbuhkan ekonomi kreatif di kalangan jamaah Majelis Ta'lim Al Hidayah warga Pamulang Regency yang sebagian merupakan ibu rumah tangga. Diharapkan sesuai dengan tujuan dari materi PKM ini, masyarakat lebih peduli akan bahaya sampah, khususnya sampah plastic, untuk itu perlu diupayakan bagaimana caranya agar sampah plastik tersebut tidak mencemari lingkungan. Dan yang lebih penting lagi keberadaan sampah plastic atau barang bekas lainnya dapat memberikan inspirasi dan ide kreatif untuk mendaur ulang sampah tersebut sebagai bentuk pengelolaan sampah, selain dapat mengurangi sampan juga diharapkan mampu menumbuhkan ekonomi kreatif mengingat sebagian warga ibu-ibunya sebagai ibu rumah tangga. 
Dalam kegaitan PKM ini, juga dipaparkan pengenalan jenis sampah dan bahayanya. Sampah dapat dibedakan berdasarkan jenisnya: 1) berdasarkan zat

kimia yang terkandung; 2) berdasarkan dapat tidaknya dibakar; 3) berdasarkan karakteristik sampah. Salah satu karakteristik sampah yaitu dapat tidaknya diuraikan. Adapun sampah plastic mempunyai karakter antara lain:

1. Butuh waktu lama untuk dapat terurai, contoh:

a. plastik : 10-20 tahun

b. botol plastik: 20 tahun

c. sterofom: tidak dapat terurai

d. kaleng alumunium: 30 tahun

e. kain nilon: 30-40 tahun

2. Merusak struktur tanah, sehingga tanah menjadi kurang subur karena unsur hara terkontaminasi oleh plastic.

3. Merusak ekosistem, jika struktur tanahnya rusak maka ekosistem tananpun akan mengalami kerusakan,

4. Memicu penyakit cancer, umumnya plastic untuk mengemas makanan, jika bereaksi dengan suhu panas plastic dan ini terjadi dalam kurun waktu lama maka dapat mengganggu kesehatan sebagai pemicu penyakit cancer.

Dari paparan di atas, maka dari itu alangkah baiknya jika sampah-sampah tersebut didaur ulang agar dapat memberikan nilai manfaat karena dapat digunakan kembali dan menumbuhkan ekonomi kreatif untuk menjadi sumber tambahan penghasilan keluarga dengan harapan dapat meningkatkan kesejahteraan keluarga. Ekonomi Kreatif merupakan kegiatan ekonomi berdasarkan pada kreativitas, keterampilan dan bakat individu untuk menciptakan daya kreasi dan daya individu yang bernilai ekonomis dan berpengaruh pada kesejahteraan masyarakat.

Kegiatan yang dihadiri oleh para ibu ini mendapat respon positif, dilihat dari antusianya menyimak materi dan dikembangkan dengan sharing berbagi pengetahuan dan pengalaman. Adapun materi dapat diklasifikasikan berdasarkan tema, yaitu:

1. Memberikan penyuluhan tentang keberadaan sampah disekitar kita dan jenisjenis sampah dan bahayanya;

2. Memberikan paparan tentang penanganan sampah dengan cara reduse (pengurangan), reuse (pemakaian kembali), dan recycle (daur ulang agar dapat dimanfaatkan;

3. Memberikan penyuluhan pada masyarakat tentang menumbuhkan ekonomi kreatif dengan memanfaatkan barang bekas atau daur ulang sampah.

Kegiatan pengabdian kepada masyarakat yang dilaksanakan dengan objek majeli ta'lim ini diselenggarakan di Mushola Al Hidayah Perumahan Pamulang Regency Benda Baru Pamulang Tangerang Selatan, ingin berbagi pengetahuan dan 
wawasan agar memberi warna topik kajian yang dilaksanakan rutin dua minggu sekali.

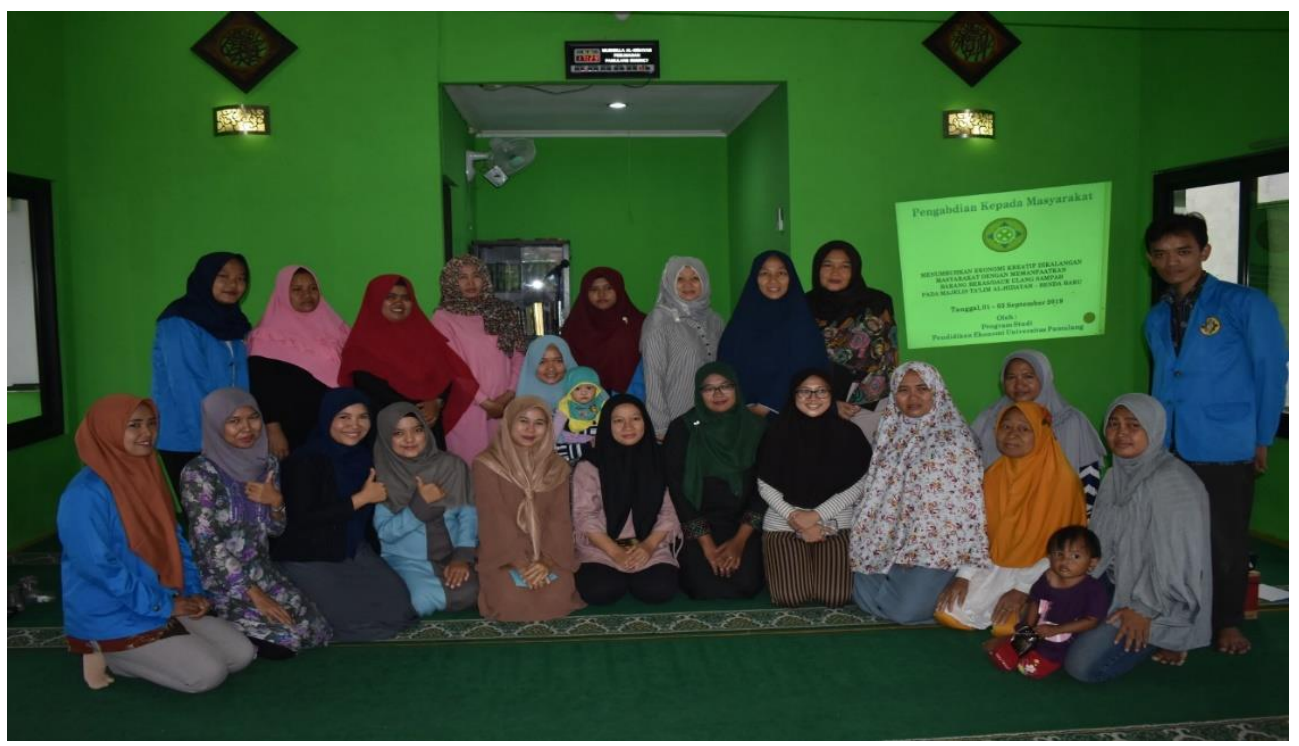

\section{Gambar 3. Sesi foto bersama tim PKM dosen dan mahasiswa Unpam} bersama ibu-ibu jamaah Majelis Ta'lim Al Hidayah

\section{KESIMPULAN DAN SARAN}

Pelaksanaan kegiatan pengabdian kepada masyarakat oleh lembaga penelitian dan pengembangan masyarakat (LPPM) Universitas Pamulang yang dilakukan oleh dosen-dosen program studi Pendidikan Ekonomi telah berjalan lancer dan mendapat respon positif dari peserta yaitu jamaah Majelis Ta'lim Al Hidayah Pamulang Regency Benda Baru Pamulang Tangerang Selatan.

Dengan adanya kegiatan ini menjadikan jamaah Majelis Ta'lim Al Hidayah Pamulang Regency Benda Baru antusias untuk menjaga kebersihan lingkungan lebih peduli pada penanganan sampah yang dimulai dari rumah tangga dengan memilah sampah sesuai jenisnya yaitu sampah organic dan non organic. Sampah non organic dapat didaur ulang menjadi hiasan ataupun barang yang memiliki nilai ekonomi yang lebih tinggi. Selain dapat menumbuhkan ekonomi kreatif juga dapat mengurangi volume sampah di masyarakat.

Selama kegiatan berjalan lancer dan mendapat respon positif dari warga jamaah Al Hidayahdapat ditunjukkan antusiasnya ibu-ibu mengikuti setiap tahapan penyuluhan dari awal hingga selesai. Juga ditunjukkan dengan kesediaan jamaah agar kegiatan ini dapat berkelanjutan pada kegiatan-kegiatan pengabdian kepada masyarakat berikutnya.

Dari kegiatan pengabdian kepada masyarakat ini diharapkan dapat memperlakukan sampah dengan bijaksana untuk menjaga lingkungan tetap bersih dan sehat. Masyarakat yang tidak saja peduli akan lingkungan tetapi juga kreatif untuk membangun ekonomi masyarakat. 


\section{DAFTAR PUSTAKA}

Gunartin, 2019, Analisa Efektivitas Bank Sampah sebagai Alternatif Pengelolaan Sampah Dalam Upaya Menuju Smart City di Kota Tangerang Selatan, Jurnal INOVASI Volume VI Nomor 1 Juni 2019, Unpam Press

Notoamodjoyo. 2007. Pendidikan dan Perilaku Kesehatan. Reneka Cipta. Jakarta.

Cetakan ke 2

Peraturan Menteri Lingkungan Hidup RI Nomor 13 Tahun 2012 adalah Pedoman Pelaksanaan Reduse, Reuse dan Recycle melalui Bank Sampah.

Sejati. 2009. Tabloid Reformata Edisi 105 April Minggu ke II. Yayasan Pelayanan Media Antiokhia

Sri Suryani, 2014, Peran Bank Sampah Dalam Efektifitas Pengelolaan Sampah (Studi Kasus Bank Sampah Malang)

Sumantri. 2010. Kesehatan Lingkungan. Kencana Prenada Media Group. Jakarta. 